\title{
Editorial
}

As JORS readers will know, last year the Journal reached the 50th anniversary of its first issue, which was published in March 1950 as the Operational Research Quarterly. It was the first journal in the field. The event was celebrated formally by an Anniversary Lunch for the editors and publishers involved over the years. Sadly, Roger Edison, one of the original founding editors, died in 1999 and the Society has lost contact with the other, Max Davies. However five of the seven subsequent editors did attend: it was an enjoyable occasion, which was recorded in the ORS Newsletter. ${ }^{1}$ A brief history of the Journal was published in OR/MS Today and includes facsimiles of the 8 different covers that have been used over the past 50 years. ${ }^{2}$

\section{Editors/Publishers of ORQ/JORS}

\begin{tabular}{|c|c|c|}
\hline Volume & Year & Editor \\
\hline $1-10$ & $1950-59$ & Max Davies and Roger Edison \\
\hline $11-14$ & $1960-63$ & $\begin{array}{l}\text { Roger Edison, Chair of Editorial } \\
\text { Committee }\end{array}$ \\
\hline $15-19$ & $1964-68$ & John Lawrence \\
\hline $20-22$ & $1969-71$ & Ray Cuninghame-Greene \\
\hline $23-31$ & $1972-80$ & Brian Haley \\
\hline $32-35$ & $1981-84$ & Peter Amiry \\
\hline $36-40$ & $1985-90$ & John Hough \\
\hline $41-47$ & $1991-96$ & Graham Rand \\
\hline \multirow[t]{4}{*}{$48-$} & $1997-$ & $\begin{array}{l}\text { John Ranyard } \\
\text { Publisher }\end{array}$ \\
\hline & $1950-67$ & Operational Research Society \\
\hline & $1968-88$ & Pergamon Press \\
\hline & $1989-$ & Palgrave (MacMillan Press) \\
\hline
\end{tabular}

The Anniversary was also marked by the republishing (as loose inserts in each of the 12 issues of volume 51) of influential papers from the last 50 years, together with a contemporary commentary. This initiative has proved to be popular and may be continued, at least on an occasional basis. It also led to a query: who have been the most prolific authors in JORS/ORQ over the past 50 years? Unfortunately it is not easy to determine this for the full 50 years until the process of archiving all past issues electronically is completed. However, thanks to information obtained from ISI, we can carry out analyses from 1981 (when the ISI journals' database was set up) to 1999. The information also enables us to find the most highly cited papers and authors over this period. In carrying out this analysis I have separated original papers (which are, of course, all refereed in the normal way) from letters/viewpoints, editorial mate- rial and 'other' (which includes meeting abstracts, corrections, book reviews etc.). The results are given in Tables 13. Note that the citations are from all journals in the ISI database, including JORS and also that some JORS papers are known to be missing.

Thus congratulations are due to JE Beasley (Imperial College) for being the most highly cited JORS author over the past 20 years; to MC Jackson (Hull University) for the most highly cited paper; and to $\mathrm{AH}$ Christer (Salford University) for publishing the most original papers. Also I would like to give a special mention to SK Goyal (Concordia University, Montreal) for the highest number of contributions to JORS in the period. Otherwise I leave it to readers to make their own interpretation of these figures, except to comment that the papers concerned are a mixture of hard and soft OR - as well as some that straddle the two types. Also I should add that these publications have been facilitated by the voluntary efforts of referees and it is a pity that it is so difficult to identify those that have been most helpful and responsive.

\section{Looking ahead}

Over the past year I have continued to appoint new members to the International Advisory Board and I would like to welcome David Ryan (New Zealand) and Tadeo Yamada (Japan). A meeting of the Board was held during the EURO conference in July, which resulted in much helpful feedback. In particular the pros and cons of alternative refereeing styles were debated but I have concluded that none have compelling advantages compared to the current single-blind refereeing (where the referee knows who the author is but not vice versa). Also, during the year,

Table 1 Most prolific authors in JORS: 1981-99 (more than 10 papers)

\begin{tabular}{lc}
\hline Author & Number of original papers \\
\hline Christer AH & 16 \\
Goyal SK & 14 \\
Laporte G & 14 \\
Williams TW & 14 \\
Beasley JE & 13 \\
Cheng TCE & 12 \\
Mehrez A & 12 \\
Paul RJ & 12 \\
Chapman C & 11 \\
Sinuary-Stern Z & 11 \\
Willis RJ & 10 \\
\hline
\end{tabular}


Table 2 Most cited papers in JORS: 1981-99 (more than 33 citations)

\begin{tabular}{|c|c|c|c|c|c|}
\hline Author & Year & Title & Volume & Page & Citations \\
\hline Jackson MC & 1984 & Towards a system of system of systems methodologies & 35 & 473 & 92 \\
\hline Beasley JE & 1990 & OR Library - distributing test problems by electronic mail & 41 & 1069 & 77 \\
\hline Dyson RG & 1988 & Reducing weight flexibility in data envelopment analysis & 39 & 563 & 68 \\
\hline Masud AS & 1981 & Interactive sequential goal programming & 32 & 391 & 59 \\
\hline Dando MR & 1981 & A Kuhnian crisis in management science & 32 & 91 & 56 \\
\hline Potts CN & 1992 & $\begin{array}{l}\text { Integrating scheduling with batching and lot sizing - a review } \\
\text { of algorithms and complexity }\end{array}$ & 43 & 395 & 56 \\
\hline Checkland P & 1985 & $\begin{array}{l}\text { From optimising to learning - a development of systems } \\
\text { thinking for the } 1990 \mathrm{~s}\end{array}$ & 36 & 757 & 55 \\
\hline Fortunyamat J & 1981 & $\begin{array}{l}\text { A representation and economic interpretation of a 2-level } \\
\text { programming problem }\end{array}$ & 32 & 783 & 55 \\
\hline Wolstenholme EF & 1983 & $\begin{array}{l}\text { The development of system dynamics as a methodology for } \\
\text { system description and qualitative analysis }\end{array}$ & 34 & 569 & 43 \\
\hline Grant TJ & 1986 & Lessons for OR from AI-a scheduling case study & 37 & 41 & 41 \\
\hline Checkland P & 1983 & OR and the systems movement-mappings and conflicts & 34 & 661 & 40 \\
\hline Jackson MC & 1990 & Beyond a system of systems methodologies & 41 & 657 & 40 \\
\hline Fildes R & 1985 & $\begin{array}{l}\text { Quantitative forecasting - the state of the art: econometric } \\
\text { models }\end{array}$ & 36 & 549 & 38 \\
\hline Dave U & 1981 & $\begin{array}{l}\% \mathrm{~T}, \mathrm{SI}<\text { policy inventory model for deteriorating items with } \\
\text { time proportional demand }\end{array}$ & 32 & 137 & 37 \\
\hline Ritchie E & 1984 & $\begin{array}{l}\text { The EOQ for linear decreasing demand-a simple optimal } \\
\text { solution }\end{array}$ & 35 & 949 & 36 \\
\hline Beasley JE & 1985 & $\begin{array}{l}\text { Algorithms for unconstrained two dimensional guillotine } \\
\text { cutting }\end{array}$ & 36 & 297 & 34 \\
\hline Drezner Z & 1984 & The p-centre problem: heuristic and optimal algorithms & 35 & 741 & 34 \\
\hline Gupta JND & 1988 & Two stage hybrid flowshop scheduling problem & 39 & 359 & 34 \\
\hline Rosenhead J & 1982 & A materialist analysis of operational research & 33 & 111 & 34 \\
\hline Wong YHB & 1990 & Restricting weight flexibility in data envelopment analysis & 41 & 829 & 34 \\
\hline
\end{tabular}

Table 3 Most cited authors in JORS: 1981-99 (more than 100 citations)

\begin{tabular}{|c|c|c|c|c|c|c|}
\hline Author & Citations & Original papers & Letters/viewpoints & Editorial material & Other & Total \\
\hline Beasley JE & 194 & 13 & - & - & 2 & 15 \\
\hline Jackson MC & 190 & 6 & 2 & 4 & 1 & 13 \\
\hline Mingers J & 155 & 9 & 1 & 2 & 2 & 14 \\
\hline Checkland P & 147 & 5 & - & 4 & 5 & 14 \\
\hline Paul RJ & 145 & 12 & - & 2 & 3 & 17 \\
\hline Christer AH & 131 & 16 & - & 2 & 5 & 23 \\
\hline Thanassoulis E & 128 & 8 & - & - & 2 & 10 \\
\hline Keys P & 123 & 5 & 4 & 2 & 1 & 12 \\
\hline Goyal SK & 107 & 14 & 20 & 6 & 2 & 42 \\
\hline Rosenhead J & 107 & 6 & 2 & 5 & 6 & 19 \\
\hline Bennett PG & 102 & 5 & 2 & - & 1 & 8 \\
\hline Dyson RG & 102 & 6 & - & 1 & 4 & 11 \\
\hline O'Keefe RM & 102 & 7 & - & 1 & 3 & 11 \\
\hline
\end{tabular}

a simplified referees report form was introduced and all referees were asked to confirm their current interests/expertise from the recently updated keywords. Our referees database is now being updated with the revised information which will enable us to match papers to referees interests more precisely.

Finally I would like to thank all involved in publishing JORS: Associate Editors Terry Williams and John Wilson; Topic Advisors Roy Johnston and Chris Potts; Editorial
Administrator Christine Faulkner; Pauline Cripps at our publishers; and Becky Gardner at our typesetters, Techset. I would also like to welcome David Bull, who has replaced Harry Holt as Publisher of JORS, and to thank him for his energetic support. MacMillan are still the publishers of JORS but Palgrave is the new imprint for their scientific publishing arm, as you will see from the front cover. I have already acknowledged our debt to referees and at last we have found a way of thanking them tangibly, through the 
opportunity to purchase books from MacMillan at significant discounts. Details will be provided shortly.

\section{An apology}

Inserted into this issue is the correct version of a paper which was published in JORS last June without the corrections that the author had made to the proof of the paper. ${ }^{3}$ I would like to apologise to $\mathrm{Mr}$ Pearson for allowing this to happen. The on-line version of the paper has now been corrected.

\section{References}

1 Cummings N (2000). Pioneering OR journal celebrated. ORS Newsletter (November) p 11.

2 Ranyard JC (2000). JORS turns 50. ORMS Today 27 (October): 36-37.

3 Pearson MA (2000). The incorporation of target performance measures and constrained optimisation in the Newsboy problem. J Opl Res Soc 51: 744-754.

John Ranyard

Editor 